\title{
Growth regulator losses from cotton plants due to rainfall
}

\author{
Rodrigo Arroyo Garcia'; Mariana Zampar Toledo ${ }^{1}$; Ciro Antonio Rosolem²* \\ ${ }^{1}$ UNESP/FCA - Programa de Pós-Graduação em Agronomia. \\ ${ }^{2}$ UNESP/FCA - Depto. de Produção Vegetal/Agricultura, R. José Barbosa de Barros, 1780 - 18610-370 - \\ Botucatu, SP - Brasil. \\ *Corresponding author <rosolem@fca.unesp.br>
}

\begin{abstract}
Plant growth regulators (PGRs) applied to cotton plants (Gossypium hirsutum L.) can be washed off by rainfall. It is expected that the closer the rainfall to spraying time, the higher the product loss and the higher the amount of product to be reapplied to reach the desired growth rate. The objective of this study was to evaluate the effects of time between rainfall and application of either mepiquat chloride or chlormequat chloride to cotton on plant growth, as well as, estimate the need for PGR reapplication. Cotton was grown in 12-L pots with soil in a greenhouse. PGRs were applied forty days after seedling emergence, when $50 \%$ of plants had one pinhead square. Rainfall was simulated 1, 2, 4, 6, or $24 \mathrm{~h}$ after spraying. Plant height was measured just before PGR application and then at 3-d intervals for $30 \mathrm{~d}$. At harvest, the number of reproductive branches and structures were counted before dry matter phytomass determination. Both growth regulators reduced cotton dry matter yields regardless of rainfall interval. PGRs controlled excessive plant growth; however, their efficiency was reduced as the time elapsed until rainfall was shorter. Product losses were detected after all rainfall intervals, which, in field conditions would require PGR reapplication. Mepiquat chloride rates to be reapplied after rain were on average $17 \%$ higher than chlormequat chloride rates.

Key words: Gossypium hirsutum L., mepiquat chloride, chlormequat chloride
\end{abstract}

\section{Perdas de reguladores de crescimento no algodoeiro devido à chuva}

\begin{abstract}
RESUMO: Reguladores de crescimento aplicados às plantas de algodoeiro (Gossypium hirsutum L.) podem ser lavados em função da ocorrência de chuvas. Chuvas que ocorrem próximas à época de aplicação podem ocasionar elevada perda e necessidade de reaplicação dos produtos visando à taxa de crescimento desejada. Avaliou-se o efeito do intervalo de tempo entre a ocorrência de chuva simulada e a aplicação de cloreto de mepiquat e cloreto de chlormequat no algodoeiro no crescimento das plantas, além de estimar a necessidade de reaplicação dos reguladores. Plantas de algodão foram cultivadas em vasos de $12 \mathrm{~L}$ que permaneceram em casa de vegetação. Os reguladores de crescimento foram aplicados 40 dias após a emergência, quando $50 \%$ das plantas apresentavam botão floral. A chuva foi simulada 1, 2, 4, 6 e 24 horas após a aplicação dos reguladores. Determinou-se a altura das plantas antes da aplicação dos produtos e a cada 3 dias até o $30^{\circ}$ dia. Na colheita, foi avaliado o número de ramos e estruturas reprodutivas, com posterior determinação da massa da matéria seca. Também foi determinado o crescimento acumulado e taxa de crescimento das plantas. Os dois reguladores reduziram a massa da matéria seca das plantas, independente do intervalo para ocorrência da chuva. O crescimento excessivo das plantas foi controlado, porém, com eficiência reduzida quanto menor o intervalo para simulação de chuva. Em todos os períodos avaliados houve perda de produtos, com necessidade de reaplicação. A taxa de reaplicação de cloreto de mepiquat para os diferentes intervalos de chuva foi, em média, 17\% maior.

Palavras-chave: Gossypium hirsutum L, cloreto de mepiquat, cloreto de chlormequat
\end{abstract}

\section{Introduction}

Rank growth is often observed in cotton (Gossypium birsutum L.) plantations on limed and well fertilized soils and favorable weather conditions. The use of plant growth regulators (PGRs) is an important agronomic countermeasure to avoid this problem (Hodges et al., 1991). Growth regulators are either natural or synthetic chemical substances that can be applied directly to plants to modify either vital or structural processes by changing hormonal balance, increasing cotton yield and quality and facilitating harvest (Laca-Buendia, 1989). The application of PGR has shown promising results, mainly in crops that have already reached a high level of technology (Ávila et al., 2008). In Brazil, mepiquat chloride and chlormequat chloride are recommended for cotton (Carvalho et al., 1994). They have similar modes of action and effects, which is to inhibit gibberellic acid biosynthesis and thus reduce cellular elongation, resulting in lower growth rate (Lamas, 2001). The technique also increases 100-seed weight and cotton boll size, enhancing early fruit opening, harvest efficiency and production of high quality fibers (Cruz et al., 1982; Reddy et al., 1992).

The effect of PGR on cotton depends on environmental conditions, such as temperature and rainfall (LacaBuendia, 1989; Marur, 1998). Rainfall in Brazilian regions where most of cotton is grown is close to $2,000 \mathrm{~mm}$ a year. Additionally, the time when PGR is applied coincides with the highest rainfall period and there is a high 
probability of the product to be rain-washed before total absorption by plants, which would require its reapplication to overcome losses. Mateus et al. (2004) worked with mepiquat chloride on cotton and observed that a $10 \mathrm{~mm}$ rainfall is enough for PGR washing. For the same PGR, Souza and Rosolem (2007) found that a 5 $\mathrm{mm}$ rainfall decreases its effects, regardless of the dose. Therefore, it is interesting to determine the need and rate of PGR to be reapplied and it is important to know whether PGR losses and reapplication would be different for distinct products. The objective of this experiment was to evaluate growth after mepiquat chloride and chlormequat chloride application associated with simulated rainfall at several intervals and to estimate an eventual reapplication rate as affected by rainfall.

\section{Material and Methods}

The experiment was carried out in a greenhouse in Botucatu, São Paulo, Brazil. The soil was Typic Haplortox (Latossolo Vermelho distrófico in the Brazilian classification) with $590 \mathrm{~g} \mathrm{~kg}^{-1}$ of sand, $340 \mathrm{~g} \mathrm{~kg}^{-1}$ of clay, and $70 \mathrm{~g} \mathrm{~kg}^{-1}$ of silt. Samples were taken from the arable layer $(0-20 \mathrm{~cm})$, air dried, sieved through a $2 \mathrm{~mm}$ mesh, and analyzed as in Raij et al. (2001). Soil chemical analysis showed $\mathrm{pH}\left(\mathrm{CaCl}_{2}\right.$ 0.01M): 3.9, M.O.: $27 \mathrm{~g}$ $\mathrm{dm}^{-3}, \mathrm{P}_{\text {resin }}: 3.0 \mathrm{mg} \mathrm{dm}^{-3}, \mathrm{H}+\mathrm{Al}^{2}: 68 \mathrm{mmol}_{\mathrm{c}} \mathrm{dm}^{-3}, \mathrm{~K}: 0.6$ mmol $\mathrm{dm}^{-3}$, Ca: $2.0 \mathrm{mmol} \mathrm{dm}^{-3}, \mathrm{Mg}: 1.0 \mathrm{mmol} \mathrm{dm}^{-3}, \mathrm{SB}:$ $3.6 \mathrm{mmol} \mathrm{dm}^{-3}$, CEC: $71.6 \mathrm{mmol} \mathrm{dm}^{-3}$ and $5 \%$ of base saturation. The field capacity of the soil sample under free draining was measured at $-0.03 \mathrm{MPa}$ using the Richards extractor (Embrapa, 1997) and the value obtained was $210 \mathrm{~g} \mathrm{~kg}^{-1}$. Dolomitic limestone was applied ( $\mathrm{CaO}: 28 \%, \mathrm{MgO}: 20 \%$ ) before the experiment to raise base saturation up to $60 \%$, according to Raij et al. (1996). The limed soil was kept in plastic bags for 30 days with water content at field capacity. Then, the soil was air dried and fertilized with $150 \mathrm{mg} \mathrm{dm}$ of $\mathrm{P}$ (simple superphosphate), $120 \mathrm{mg} \mathrm{dm}^{-3}$ of $\mathrm{K}(\mathrm{KCl})$ and $50 \mathrm{mg} \mathrm{dm}^{-3}$ of $\mathrm{N}$ (urea).

Five cotton seeds (Gossypium hirsutum L., var. Latifolia, cv. Delta Opal) were sown in each 12-L pot. Main characteristics of the cotton cultivar include 150$170 \mathrm{~cm}, 52-60$ days to flowering, resistance to lodging and yield of $5,250 \mathrm{~kg} \mathrm{ha}^{-1}$ (Maeda Deltapine Monsanto Algodão, 2001).

Soil water content was kept close to $80 \%$ of field capacity. Ten days after emergence, seedlings were thinned down to two per pot. Hoagland and Arnon nutrient solution was applied on the same day. Greenhouse temperature was kept at $25-30^{\circ} \mathrm{C}$ during the experiment. The experimental design was a completely randomized block, with four replicates, analyzed as a $2 \times 5$ factorial with one additional treatment (control, without GR).

Mepiquat chloride or chlormequat chloride, $25 \mathrm{~g} \mathrm{ha}^{-1}$ i.a., were applied using $150 \mathrm{~L} \mathrm{ha}^{-1}$ of solution, 40 days after seedling emergence, when $50 \%$ of the plants had at least one flower bud (pinhead square). Rainfall $(20 \mathrm{~mm})$ was simulated in different intervals after spraying. Tem- perature and relative humidity at application time were $26.5^{\circ} \mathrm{C}$ and $70 \%$, respectively. Treatments consisted of two GRs, five rainfall simulation intervals $(1,2,4,6$ or $24 \mathrm{~h}$ after GR application) and a control.

The spraying and rainfall simulation equipment was set up indoors. It was composed of a 3-m high and 2-m wide metal frame with a carriage coupled $2.5 \mathrm{~m}$ overhead. Two spraying bars were fixed to the carriage, a pesticide sprayer and a rainfall simulator, both with 6$\mathrm{m}$ horizontal displacement. The experimental units were arranged along the simulator according to the spacing normally used in cotton plantations $(0.90 \mathrm{~m})$. The spraying bar had four conic nozzles (Dx 8) $0.50 \mathrm{~m}$ apart and $0.50 \mathrm{~m}$ away from the plant canopy. The system operating pressure and displacement speed were $3.43 \mathrm{MPa}$ and $1.0 \mathrm{~m} \mathrm{~s}^{-1}\left(3.6 \mathrm{~km} \mathrm{~h}^{-1}\right)$, respectively. Pots remained on the floor and the sprayer was $1.75 \mathrm{~m}$ above. The rainfall simulator bar had 3 high-flow nozzles (TK-SS-20) $0.5 \mathrm{~m}$ apart. Rainfall simulation was produced with a working pressure of $0.81 \mathrm{MPa}$ and displacement speed of $0.0526 \mathrm{~m} \mathrm{~s}^{-1}$, resulting the application of a $2.5 \mathrm{~mm}$ rainfall each pass. The maximum and minimum temperatures during the experiment were recorded daily, using portable electronic equipment located in the center of the greenhouse $1 \mathrm{~m}$ above the floor.

Plant height was measured from soil surface up to the last vegetative node, immediately before PGR application and in 3-day intervals for 30 days. A ruler was used to measure height of two plants per experimental unit to obtain a mean value. Plant cumulative growth was calculated based on the number of days after PGR spraying. Then, growth rates were calculated by deriving the equations fitted to growth curves. Based on plant growth rate 17 days after spraying, which was long enough for the expression of the GR effect and thus differences in plant growth rates at different rainfall times, it was estimated the need for GR reapplication. The 24$\mathrm{h}$ interval was considered as maximum absorption and thus reapplication was not necessary.

The experiment was harvested 30 days after GR application, when the number of reproductive branches and structures (flower, fruit, and boll) were recorded. Then, plants were dried in an oven at $60^{\circ} \mathrm{C}$ for $72 \mathrm{~h}$ and dry matter phytomass was determined.

Data obtained for reproductive branches and structures, dry matter phytomass, and plant height after PGR application was submitted to ANOVA and means were compared using the t test $(\alpha=0.05)$. Then, for each analysis, each of the ten treatments was compared with the control by the Dunnet test at $5 \%$. Response curves were fitted for cumulative plant growth; the model with the highest significant determination coefficient $\left(R^{2}\right)$ was chosen.

\section{Results and Discussion}

There was a significant interaction between the effects of growth regulators and rainfall intervals on the number of reproductive structures but it was not pos- 
sible to establish a cause-effect relation (Table 1). However, no differences were observed when the results obtained for plants treated with PGR were compared with the control. Similar finding was reported by Souza and Rosolem (2007) when they applied mepiquat chloride and simulated rainfall after $90 \mathrm{~min}$ and the number of cotton reproductive structures was not affected. Effects of these growth regulators on fruit retention have been inconsistent. Higher retention was observed by Hodges et al. (1991) and Biles and Cothren (2001), but Nagashima et al. (2005) reported that cotton seeds treated with mepiquat chloride resulted in plants with a smaller number of flower buds. Differences among the results may be due to temperature oscillations during the experimental period, plant age, used doses, evaluation method and others.

Treatment effects on the number of reproductive branches (Table 2) and structures (Table 1) were similar, and no response was observed in relation to the control. Differences were only observed for the interactions among treatments. The effect on the number of reproductive branches may vary according to growth regulator rate (Lamas, 2000), time and amount of simulated rainfall (Mateus et al., 2004; Souza and Rosolem, 2007). The number of nodes in the main stem is important for cotton yield for fruiting branches are formed from these structures (Mauney, 1986). Nagashima et al. (2007), conducting an experiment under field conditions, reported that the number of reproductive branches decreased when mepiquat chloride was applied; however, it was used in successive leaf applica- tions, while in our study there was just one single spray. The lack of response to mepiquat chloride under environment with no limiting seasonal heat units is consistent with some research in the USA (Kerby, 1985). However, Yeates et al. (2002) observed in an experiment conducted in field conditions that higher yield could be expected from untreated plants due to mepiquat chloride reducing the number of main-stem fruiting branches, but this was not the case. Compensation for fewer fruiting branches in treated plants occurred through a higher proportion of retained bolls and vegetative growth (Yeates et al., 2002). Thus, the tendency for increased yields (10.65\% for untreated plants) with intermediate amounts of mepiquat chloride applied before first flower, is due to the action of the product in reaching a balance among the important components that affect yield (Yeates et al., 2002).

Cotton plant dry matter did not vary neither with the growth regulator used, rainfall interval nor their combination (Table 3). On the other hand, cotton plant dry matter decreased and it was lower than the control. Even after only $1 \mathrm{~h}$ for product absorption, dry matter decreased sharply for both growth regulators. Thus, smaller plant height and dry matter production were observed even without the complete absorption of the growth regulators. Similar results were found by Souza and Rosolem (2007), but Mateus et al. (2004) observed a compensatory gain due to leaf thickening and an increased leaf area, despite the reduced height after the application of mepiquat chloride, which did not affect cotton plant dry matter.

Table 1 - Number of fruiting structures affected by simulated rainfall 30 days after growth regulator spraying.

\begin{tabular}{|c|c|c|c|c|c|c|}
\hline \multirow{2}{*}{ Growth Regulator } & \multicolumn{6}{|c|}{ Time to rainfall $(\mathrm{h})$} \\
\hline & 1 & 2 & 4 & 6 & 24 & Mean \\
\hline Mepiquat chloride & $9.0 \mathrm{aB}^{(1)}$ & $8.3 \mathrm{aB}$ & $11.3 \mathrm{aA}$ & $8.5 \mathrm{bB}$ & $9.3 \mathrm{aB}$ & 9.3 \\
\hline Chlormequat chloride & $10.3 \mathrm{aA}$ & $8.3 \mathrm{aB}$ & $7.3 \mathrm{bB}$ & $10.5 \mathrm{aA}$ & $9.0 \mathrm{aAB}$ & 9.1 \\
\hline Mean & 9.6 & 8.3 & 9.3 & 9.5 & 9.1 & \\
\hline Control $^{(2)}$ & \multicolumn{6}{|c|}{$9.3^{\text {ns }}$} \\
\hline Coefficient of Variation (\%) & \multicolumn{6}{|c|}{14.7} \\
\hline
\end{tabular}

Table 2 - Number of reproductive branches affected by simulated rainfall 30 days after growth regulator spraying.

\begin{tabular}{lcccccc}
\hline \multirow{2}{*}{ Growth Regulator } & \multicolumn{5}{c}{ Time to rainfall $(\mathrm{h})$} \\
\cline { 2 - 7 } & \multicolumn{1}{c}{1} & 2 & 4 & 6 & 24 & Mean \\
\hline Mepiquat chloride & $10.5 \mathrm{aAB}^{(1)}$ & $9.5 \mathrm{aB}$ & $11.8 \mathrm{aA}$ & $10.0 \mathrm{aB}$ & $9.5 \mathrm{aB}$ & 10.3 \\
Chlormequat chloride & $10.0 \mathrm{aA}$ & $10.0 \mathrm{aA}$ & $9.3 \mathrm{bA}$ & $10.0 \mathrm{aA}$ & $10.0 \mathrm{aA}$ & 9.9 \\
Mean & 10.3 & 9.8 & 10.5 & 10.0 & 9.8 \\
Control(2) & & \multicolumn{4}{c}{$10.8^{\text {ns }}$} \\
Coefficient of Variation (\%) & & \multicolumn{4}{c}{10.4} \\
\hline
\end{tabular}

${ }^{(1)}$ Means followed by the same small letter in the column and capital letter in the row do not differ (LSD, $\left.p \leq 0.05\right)$. ${ }^{(2)}$ Control without growth regulator spraying used as reference for individual comparison with each of the treatments, (Dunnet, $p \leq 0.05)$. ns: non significant. 
Total growth of cotton plants measured between the application of the regulators and plot disassembly was larger when mepiquat chloride was applied (Table 4). It was also observed that the rainfall interval affected plant growth, which was generally smaller the longer the rainfall interval. Therefore, as the initial working hypothesis established, rainfall may cause growth regulator losses and product reapplication may be necessary. Compared to the control, only the 1-h rainfall interval was not sufficient for the treatments with neither mepiquat chloride nor chlormequat chloride to differ from each other, although product washing was evidenced in both cases.

At the end of the experiment ( 30 days after treatment or accumulated 397-degrees-day), total plant growth varied with the rainfall interval for the two regulators tested (Figure 1). Thus, the later the interval for rainfall simulation, the smaller the plant growth. Simulated rainfall 1 hour after the application of the growth regulators resulted in higher growth than in the other intervals, evidencing growth regulator losses due to product washing. The difference among treatments was visible eight days after the application and increased until the end of the experiment. Therefore, when compared to the 24-h interval (maximum absorption), all studied conditions required partial reapplication of the growth regulator for better controlling of the excessive plant growth as measured by the cotton plant height. Coversely, the 1-h interval was enough for the regulators to exert their effect, as cotton plant growth was different from the control. The effects of mepiquat chloride and other bioregulators on cotton plants depend on several factors such aslike temperature and rainfall (Athayde and Lamas, 1999). Mateus et al. (2004) and Souza and Rosolem (2007) found that the simulation of rainfall right after mepiquat chloride application increases its losses; rainfall and growth regulator dose also influence product washing.

The plant growth rate as affected by rainfall interval was similar for both growth regulators (Figure 2). As expected, the growth rate of the cotton plants was larger when rainfall was simulated right after the application of the regulators and reduced as time passed (Mateus et al., 2004). From $6 \mathrm{~h}$ on, growth rate tended to remain constant. The use of chlormequat chloride resulted in a lower growth rate in the shorter intervals between growth regulator application and $20 \mathrm{~mm}$-rainfall simulation. Similar results were observed for mepiquat chloride and chlormequat chloride at larger intervals for rainfall (Figure 2). Therefore, chlormequat chloride was more efficient when its application was closer to simulated rainfall than mepiquat chloride.

The growth rates allowed determining the reapplication dose of each product as affected by rainfall interval (Table 5). As the 24-h period was enough for the complete absorption of the growth regulators, the reapplication dose was not calculated. For the 4-h interval, the reapplication dose of mepiquat chloride was larger than for the 2-h interval, which may be explained by the

Table 3 - Cotton dry matter affected by simulated rainfall 30 days after growth regulator spraying.

\begin{tabular}{|c|c|c|c|c|c|c|}
\hline \multirow{2}{*}{ Growth Regulator } & \multicolumn{6}{|c|}{ Time to rainfall (h) } \\
\hline & 1 & 2 & 4 & 6 & 24 & Mean \\
\hline & \multicolumn{6}{|c|}{ g per pot } \\
\hline Mepiquat chloride & $21.2 * \%$ & $22.1 * *$ & $25.5^{*}$ & $19.9 * *$ & $17.9 * *$ & 21.3 \\
\hline Chlormequat chloride & $22.4 * \%$ & $23.2 * \%$ & $21.3 * \%$ & $25.7 *$ & $20.9 * \%$ & 22.7 \\
\hline Mean & 21.8 & 22.7 & 23.4 & 22.8 & 19.4 & \\
\hline Control & \multicolumn{6}{|c|}{35.9} \\
\hline Coefficient of Variation (\%) & \multicolumn{6}{|c|}{23.4} \\
\hline
\end{tabular}

Table 4 - Cotton total growth affected by simulated rainfall 30 days after growth regulator spraying.

\begin{tabular}{|c|c|c|c|c|c|c|}
\hline \multirow{2}{*}{ Growth Regulator } & \multicolumn{6}{|c|}{ Time to rainfall (h) } \\
\hline & 1 & 2 & 4 & 6 & 24 & Mean \\
\hline & \multicolumn{6}{|c|}{ 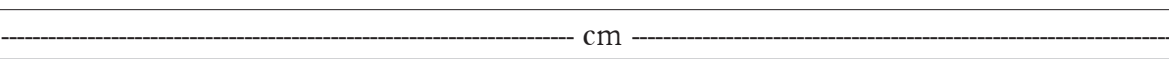 } \\
\hline Mepiquat chloride & 26.9 & $21.7 *$ & $21.9 *$ & $17.0 \% *$ & $12.1 * *$ & $19.9 \mathrm{a}$ \\
\hline Chlormequat chloride & 24.9 & $19.4 * \%$ & $16.9 * \%$ & $15.6 \% *$ & $13.0 \% *$ & $17.9 \mathrm{~b}$ \\
\hline Mean & $25.9 \mathrm{~A}^{(1)}$ & $20.6 \mathrm{~B}$ & $19.4 \mathrm{~B}$ & $16.3 \mathrm{C}$ & $12.6 \mathrm{D}$ & \\
\hline Control $^{(2)}$ & \multicolumn{6}{|c|}{29.2} \\
\hline Coefficient of Variation (\%) & \multicolumn{6}{|c|}{15.7} \\
\hline
\end{tabular}

${ }^{(1)}$ Means followed by the same small letter in the column and capital letter in the row do not differ (LSD, $\left.p \leq 0.05\right)$. ${ }^{(2)}$ Control without growth regulator spraying used as reference for individual comparison with each of the treatments, (Dunnet, $p \leq 0.05)$. ** and * significant at $p \leq 0.01$ and $p \leq 0.05$, respectively. 


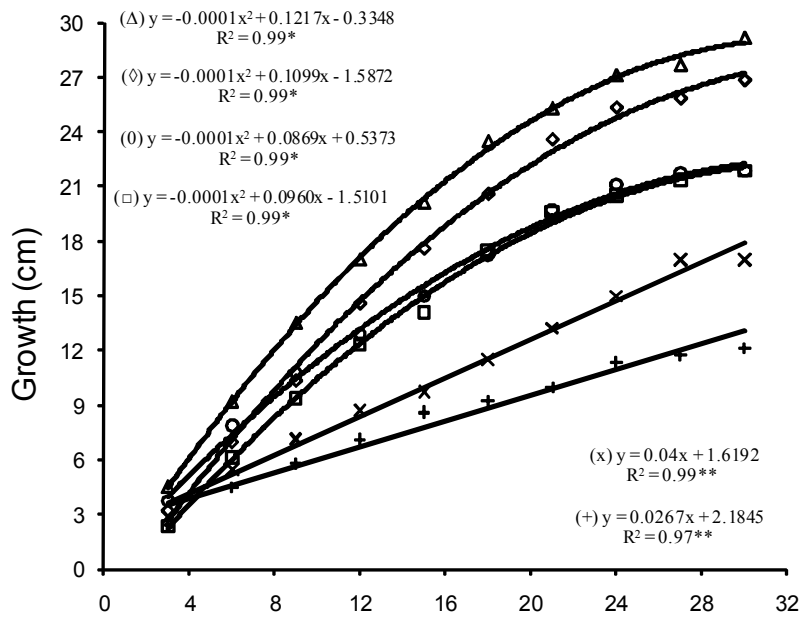

A)

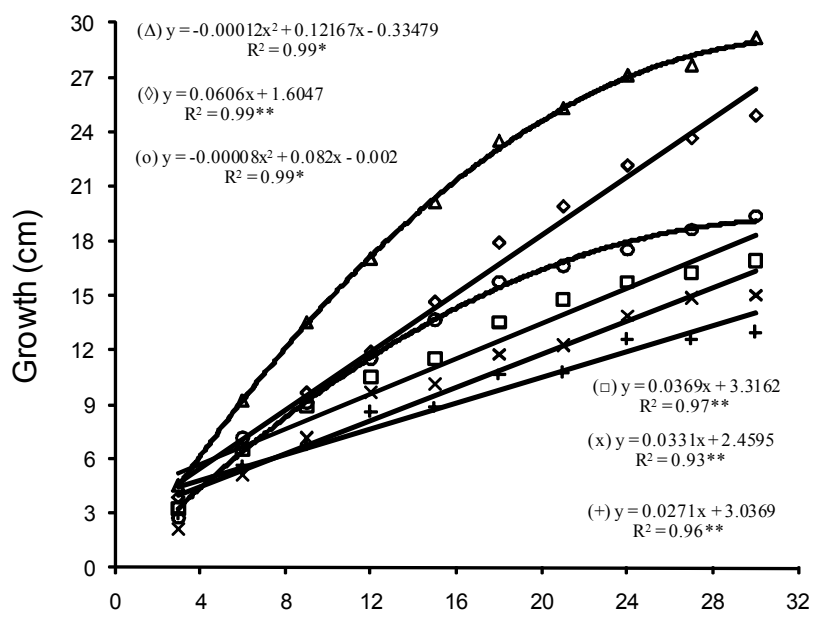

B)

Days after treatment

Figure 1 - Cotton growth after mepiquat chloride (A) or chlormequat chloride (B) spraying in different times to rainfall. $(\Delta)$ : control, $(\diamond): 1 \mathrm{~h},(\mathrm{o}): 2 \mathrm{~h},(\square): 4$ $\mathrm{h},(\mathrm{x}): 6 \mathrm{~h}$ and $(+): 24 \mathrm{~h} . *$ and $* *$ : significant at $p \leq$ 0.01 and $p \leq 005$, respectively.

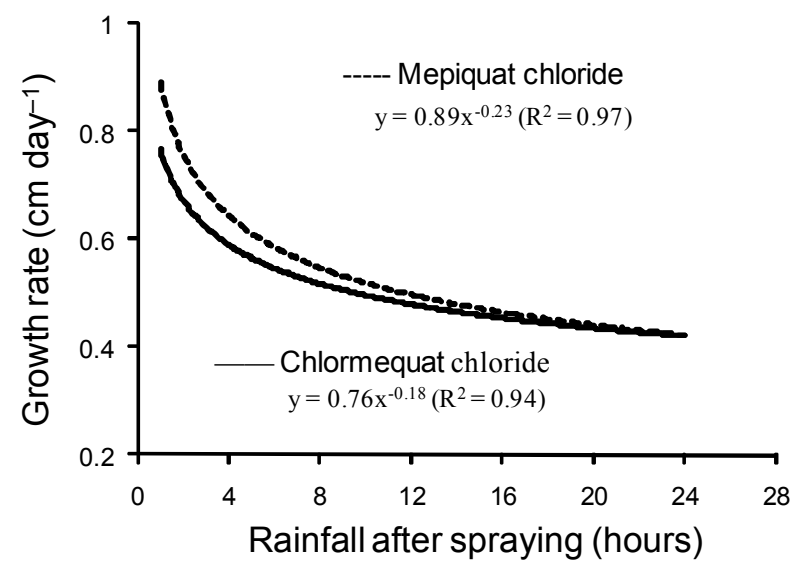

Figure 2 - Cotton growth rate as affected by time to rainfall after spraying.
Table 5 - Mepiquat chloride and chlormequat chloride reapplication in cotton as affected by time to rainfall.

\begin{tabular}{lcc}
\hline Time to rainfall & $\begin{array}{c}\text { Mepiquat } \\
\text { chloride }\end{array}$ & $\begin{array}{c}\text { Chlormequat } \\
\text { chloride }\end{array}$ \\
\hline h & 35 & 30 \\
\hline 1 & 26 & 26 \\
\hline 2 & 30 & 21 \\
4 & 19 & 15 \\
6 & 0 & 0 \\
\hline 24 & & \\
\hline
\end{tabular}

higher growth rate 17 days after treatment (moment of the reapplication calculation). In general, rainfall simulation in cotton right after the application of growth regulators requires considerable reapplication due to product washing. Nevertheless, intervals longer than 6 h may reduce the reapplication dose to less than $20 \%$. Mepiquat chloride rates to be reapplied after rain were, in average $17 \%$ higher than chlormequat chloride rates.

\section{References}

Athayde, M.L.F.; Lamas, F.M. 1999. Sequential applications of mepiquat chloride in cotton plants. Pesquisa Agropecuária Brasileira 34: 369-375 (in Portuguese, with abstract in English). Ávila, M.R.; Braccini, A.L.; Scapim, C.A.; Albrecht, L.P.; Tonin, T.A.; Stülp, M. 2008. Bioregulator application, agronomic efficiency, and quality of soybean seeds. Scientia Agricola 65: 604-612.

Biles, S.P.; Cothren, J.T. 2001. Flowering and yield response of cotton to application of mepiquat chloride and PGR-IV. Crop Science 41: 1834-1837.

Carvalho, L.H.; Chiavegato, E.J.; Cia, E.; Kondo, J.I.; Sabino, J.C.; Pettinelli Jr., A.; Bortoletto, N.; Gallo, P.B. 1994. Effects of growth phytoregulators and pruning on the cotton crop. Bragantia 53: 247-254 (in Portuguese, with abstract in English).

Cruz, L.S.F.; Sabino, N.P.; Toledo, N.M.P. 1982. Effects of mepiquat chloride used as a phytoregulator on cotton plants (Gossypium birsutum L. 'IAC 16'). Planta Daninha 1: 15-22 (in Portuguese, with abstract in English).

Empresa Brasileira de Pesquisa Agropecuária [EMBRAPA]. 1997. Handbook for Soil Analysis. 2ed. Centro Nacional de Pesquisa de Solos, Rio de Janeiro, RJ, Brazil. (in Portuguese).

Empresa Brasileira de Pesquisa Agropecuária [EMBRAPA]. 1999. Brazilian System for Soil Classification. Centro Nacional de Pesquisa de Solos, Rio de Janeiro, RJ, Brazil. (in Portuguese).

Hodges, H.F.; Reddy, V.R.; Reddy, K.R. 1991. Mepiquat chloride and temperature effects on photosynthesis and respiration of fruiting cotton. Crop Science 31: 1301-1308.

Kerby, T.A. 1985. Cotton response to mepiquat chloride. Agronomy Journal 77: 907-912.

Laca-Buendia, J.P. 1989. Effect of dosis of plant growth regulators on cotton (Gossypium hirsutum L.). Revista Brasileira de Fisiologia Vegetal 1: 109-113. (in Portuguese, with abstract in English).

Lamas, F.M. 2001. Comparative study of mepiquat chloride and chlormequat chloride application in cotton. Pesquisa Agropecuária Brasileira 36: 265-272. (in Portuguese, with abstract in English).

Lamas, F.M. 2000. Reactions of cotton CNPA-ITA 90 to mepiquat chloride. Pesquisa Agropecuária Brasileira 35: 507-516. (in Portuguese, with abstract in English). 
Maeda Deltapine Monsanto Algodão. 2001. DeltaOPAL Technical Guide. Monsanto, Uberlândia, MG, Brazil. (in Portuguese).

Marur, C.J. 1998. Photosynthesis and translocation of sugars in cotton plants subjected to drought stress after mepiquat chloride application. Revista Brasileira de Fisiologia Vegetal 10: 59-64. (in Portuguese, with abstract in English).

Mateus, G.P.; Lima, E.V.; Rosolem, C.A. 2004. Mepiquat chloride loss by simulated rain. Pesquisa Agropecuária Brasileira 39: 631-636. (in Portuguese, with abstract in English).

Mauney, J.R. 1986. Vegetative growth and development of fruiting rites. p.11-28. In: Mauney, J.R.; Stewart, J.M., eds. Cotton physiology. The Cotton Foundation, Memphis, TN, USA.

Nagashima, G.T.; Marur, C.J.; Yamaoka, R.S.; Miglioranza, E. 2005. Development of cotton plant from seeds soaked with mepiquat chloride. Pesquisa Agropecuária Brasileira 40: 943946. (in Portuguese, with abstract in English).

Nagashima, G.T.; Miglioranza, E.; Marur, C.J.; Yamaoka, R.S.; Gomes, J.C. 2007. Soaking seeds and foliar application with mepiquat chloride on growth and yield of cotton plant. Ciência e Agrotecnologia 31: 1027-1034. (in Portuguese, with abstract in English).
Raij, B. van.; Cantarella, H.; Quaggio, J.A.; Furlani, A.M.C. 1996. Fertilization and Liming Recommendation For the State of São Paulo. 2ed. Instituto Agronômico/ Fundação IAC, Campinas, SP, Brazil. (in Portuguese).

Raij, B. van.; Andrade, J.C.; Cantarella, H.; Quaggio, J.A. 2001. Chemical Analysis for Evaluation of the Fertility of Tropical Soils. Instituto Agronômico, Campinas, SP, Brazil. (in Portuguese).

Reddy, V.R.; Trent, A.; Acock, B. 1992. Mepiquat chloride and irrigation versus cotton growth and development. Agronomy Journal 84: 930-933.

Souza, F.S.; Rosolem, C.A. 2007. Rainfall intensity and mepiquat chloride persistence in cotton. Scientia Agricola 64: 125-130.

Yeates, S.J.; Constable, G.A.; McCumstie, T. 2002. Developing management options for mepiquat chloride in tropical winter season cotton. Field Crops Research 74: 217-230.

Received September 19, 2008

Accepted November 17, 2009 